\title{
CHANGES IN THE CHARACTERISTICS OF TOOL STEEL AFTER AEROTHERMOACOUSTIC TREATMENT
}

Atroshenko S.A.

Institute for Problems in Mechanical Engineering of the Russian Academy of Sciences, Saint-Petersburg, Russia

\begin{abstract}
This paper looks at ways to improve the characteristics of rapid steels. The authors try to understand how the microstructure changes during aerothermoacoustic treatment in comparison with conventional heat treatment techniques and what changes are typical of rapid steels under the aforementioned treatment. The main result of this work is an understanding of how different aerothermoacoustic treatment regimes influence the behavior of rapid steels. It was established that aerothermoacoustic treatment can be used to enhance the strength characteristics of rapid steels. A qualimetric analysis was carried out to estimate the effect of aerothermoacoustic processing on the characteristics of tool steels.
\end{abstract}

Keywords: aerothermoacoustic treatment, rapid steels, strength characteristics.

\section{Introduction}

Among the many hardening methods, it is promising to use the ability to control the characteristics of metals and alloys (hardness, wear resistance, ductility, cold resistance and corrosion resistance) by means of their structural and phase changes, which are realized in metals under the influence of powerful acoustic fields. Aerothermoacoustic treatment (ATAT) [1-3] is one of the combined means of influence on materials. When it is carried out, the effect of temperature and acoustic fields is realized in order to form the material properties in the desired direction both in the entire volume (the depth of the hardened layer is determined by the hardenability of the steel) and in the surface layer.

The present work is devoted to the experimental study of the microstructure of rapid steels after aerothermoacoustic treatment in combination with standard heat treatment (SHT) in various combinations and to elucidate the physical mechanisms that cause changes in mechanical and structural characteristics that determine the indices of durability and strength.

\section{Materials and experimental technique}

Materials for the study were: rapid steel grade R6M5 and American rapid steel grades HCV and HS. These materials were metallographically examined after aerothermoacoustic treatment and for comparison after standard heat treatment.

Studies of the microstructure were carried out on an optical microscope Neophot-32 on metallographic sections after chemical etching.

The microhardness was determined by the Vick- ers method on the PMT-3 device at a load of $100 \mathrm{~g}$. To study the change in the structure of rapid steel grade R6M5 from the surface to the center, the panoramas of the change in microhardness from the surface of the section to the middle were taken.

\section{Results and discussion}

The microstructure of the R6M5 steel drills in the initial state - after the standard heat treatment (SHT) consists of light carbides and dark grains of tempered martensite. The structure of the drill made from the same material after aerothermoacoustic treatment and after work as a cutting tool is not significantly different. The results of the quantitative characteristics of the structure in the initial and processed states are given in Table $\mathbf{1}$.

As can be seen, as a result of aerothermoacoustic processing, the grain size decreases and the carbides are crushed both small and large. In addition, carbides are distributed more evenly in the treated material. The increase in microhardness in the material after ATAT in comparison with the initial one (Table 1) is related to the homogenization of the structure. The table shows average values of microhardness measurements $\left(\mathrm{HV}_{\text {average }}\right)$, as well as minimum $\left(\mathrm{HV}_{\min }\right)$ and maximum $\left(\mathrm{HV}_{\max }\right)$ for the estimating the spread of microhardness values. Since the diameter of indentation was $12-13 \mu \mathrm{m}$, and the size of the carbide phase and grains of the $\alpha$-solid solution is much smaller (from 2 to $7 \mu \mathrm{m}$ ), the microhardness is an integral one, characterizing the microhardness of both these phases and the uniformity of carbide distribution in the solid solution.

(C) Atroshenko S.A., 2018 
Table 1

Table 3

Results of quantitative characteristics of the structure of steel R6M5

\begin{tabular}{|c|c|c|c|c|c|c|}
\hline Material & \multirow{2}{*}{$\begin{array}{c}\text { srain } \\
\text { size, } \\
\mu \mathrm{m}\end{array}$} & \multicolumn{2}{|c|}{$\begin{array}{c}\text { Carbide } \\
\text { size, } \mu \mathrm{m}\end{array}$} & $\begin{array}{c}\mathrm{HV}_{\text {average }} \\
\mathrm{MPa}\end{array}$ & $\begin{array}{c}\mathrm{HV}_{\text {min }}, \\
\mathrm{MPa}\end{array}$ & $\begin{array}{c}\mathrm{HV}_{\text {max }}, \\
\mathrm{MPa}\end{array}$ \\
\hline $\begin{array}{c}\text { R6M5 } \\
\text { (SHT) }\end{array}$ & 6,30 & 2,65 & 7,67 & 739 & 642 & 824 \\
\hline $\begin{array}{c}\text { R6M5 } \\
\text { (ATAT) }\end{array}$ & 5,67 & 2,05 & 7,47 & 860 & 642 & 1097 \\
\hline
\end{tabular}

To control the quality of drills of different lengths and diameters, the microhardness of the initial (after SHT) and the drills after ATAT was measured. The results of measuring eight drills are given in Table 2.

Table 2

Results of measuring the microhardness of drills

\begin{tabular}{|c|c|c|c|c|c|}
\hline № & Drill size & \begin{tabular}{|l|} 
Treat \\
ment
\end{tabular} & $\begin{array}{l}\mathrm{HV}_{\min }, \\
\mathrm{MPa}\end{array}$ & $\begin{array}{c}\mathrm{HV}_{\text {average, }} \\
\mathrm{MPa}\end{array}$ & $\begin{array}{c}\mathrm{HV}_{\max }, \\
\mathrm{MPa}\end{array}$ \\
\hline 1 & \multirow{2}{*}{$\begin{array}{l}\varnothing 3 \mathrm{~mm} l \\
=135 \mathrm{~mm}\end{array}$} & SHT & 572 & 824 & 1097 \\
\hline 2 & & ATAT & 824 & 1097 & 1288 \\
\hline 3 & \multirow{2}{*}{$\begin{array}{l}\varnothing 7 \mathrm{~mm} l \\
=135 \mathrm{~mm}\end{array}$} & SHT & 624 & 824 & 1288 \\
\hline 4 & & ATAT & 824 & 946 & 1288 \\
\hline 5 & \multirow{2}{*}{$\begin{array}{l}\varnothing 3,5 \mathrm{~mm} \\
l=70 \mathrm{~mm}\end{array}$} & SHT & 642 & 946 & 1097 \\
\hline 6 & & ATAT & 946 & 1097 & 1288 \\
\hline 7 & \multirow{2}{*}{$\begin{array}{l}\varnothing 5 \mathrm{~mm} l \\
=135 \mathrm{~mm}\end{array}$} & SHT & 572 & 724 & 1097 \\
\hline 8 & & ATAT & 724 & 946 & 1288 \\
\hline
\end{tabular}

According to the results it can be seen that the microhardness of the drills after aerothermoacoustic processing is much higher than the similar values after SHT.

After SHT, 28 holes were drilled, and after the ATAO - 192 holes. The structure of Ø3,6 mm drills was examined after testing at the Sestroretsk Instrument Factory. Table 3 shows the characteristics of the structure in the surface layer and in the center of rapid steel drills.

It can be seen that in the treated drill in the surface layer the size of the large carbides is somewhat smaller than in the center, and the smaller is slightly larger, i.e. the averaging of carbides in the surface occurred, the grain size remained practically unchanged; In the initial state, the structure is almost identical on the surface and in the center.

Thus, in the surface layer of the material, after the treatment, the structure is aligned. Homogenization leads to a higher complex of mechanical properties of the material. and in the center of high-speed steel drills

\begin{tabular}{|c|c|c|c|c|c|c|}
\hline \multirow{2}{*}{ Material } & $\begin{array}{c}\text { Grain } \\
\text { size, } \\
\mu \mathrm{m}\end{array}$ & \multicolumn{2}{|c|}{$\begin{array}{c}\text { Carbide } \\
\text { size, } \mu \mathrm{m}\end{array}$} & $\begin{array}{c}\mathrm{HV}_{\text {average }} \\
\mathrm{MPa}\end{array}$ & $\begin{array}{c}\mathrm{HV}_{\text {min }}, \\
\mathrm{MPa}\end{array}$ & $\begin{array}{c}\mathrm{HV}_{\text {max }}, \\
\mathrm{MPa}\end{array}$ \\
\hline $\begin{array}{c}\text { R6M5 } \\
\text { (SHT- } \\
\text { surface) }\end{array}$ & 6,40 & 2,73 & 7,60 & 680 & 642 & 724 \\
\hline $\begin{array}{c}\text { R6M5 } \\
\text { (ATAT- } \\
\text { surface) }\end{array}$ & 5,80 & 2,33 & 7,13 & 640 & 572 & 724 \\
\hline $\begin{array}{c}\text { R6M5 } \\
\text { (SHT- } \\
\text { base } \\
\text { metal) }\end{array}$ & 6,53 & 2,60 & 7,60 & 743 & 572 & 946 \\
\hline $\begin{array}{c}\text { R6M5 } \\
\text { (ATAT- } \\
\text { base } \\
\text { metal }\end{array}$ & 5,60 & 1,87 & 7,27 & 799 & 642 & 946 \\
\hline
\end{tabular}

Since the processing temperature does not exceed the temperature of the phase transformations, these structural changes can result from a change in the concentration of point defects, the formation of new dislocations and microdefects of packing by their interaction and redistribution, as well as the result of redistribution of the elements dissolved in the solid phase, which can be caused by thermal diffusion at multiple heating and cooling.

A factor that increases the characteristics of steels can be a thermo-hardening, because when heated and cooled, structural components, having different physical properties (heat capacity, thermal conductivity, coefficient of thermal expansion) and strength, experience internal microplastic deformation, which can also cause internal stress.

The structure of the R6M5 steel drills in the transverse and longitudinal sections is practically the same. The structure of American drills also represents tempered martensite and carbides. Drills of steel grade $\mathrm{HCV}$ in the longitudinal and cross sections have the same structure, and of steel HS - different.

In the HS steel, in the longitudinal section (Fig. 1-1), the carbide banding is visible.

These accumulations of carbides cause a lower microhardness (Table 4). In addition, this steel has a rather large amount of residual austenite, which can also explain the low microhardness for rapid steel.

The diagram of the change in microhardness from the surface to the center of the section after standard and aerothermoacoustic processing is shown in Fig. 2.
Characteristics of the structure in the surface layer 

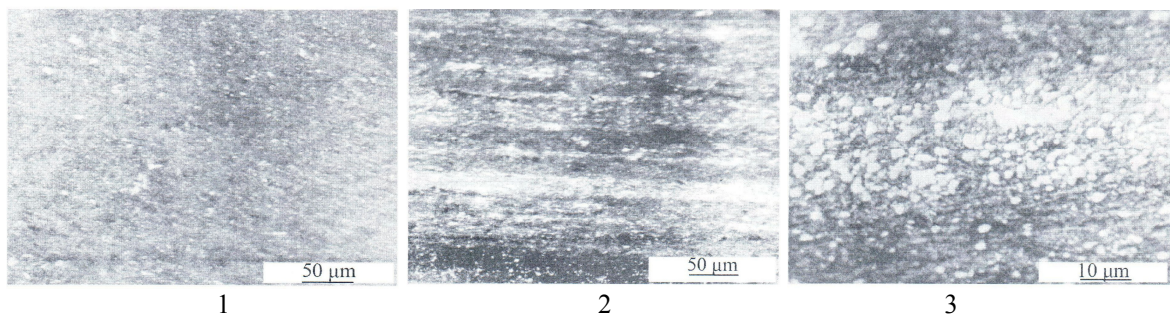

Fig. 1. Structure of US rapid steel HS after standard processing, along (1) and across $(2,3)$ textures

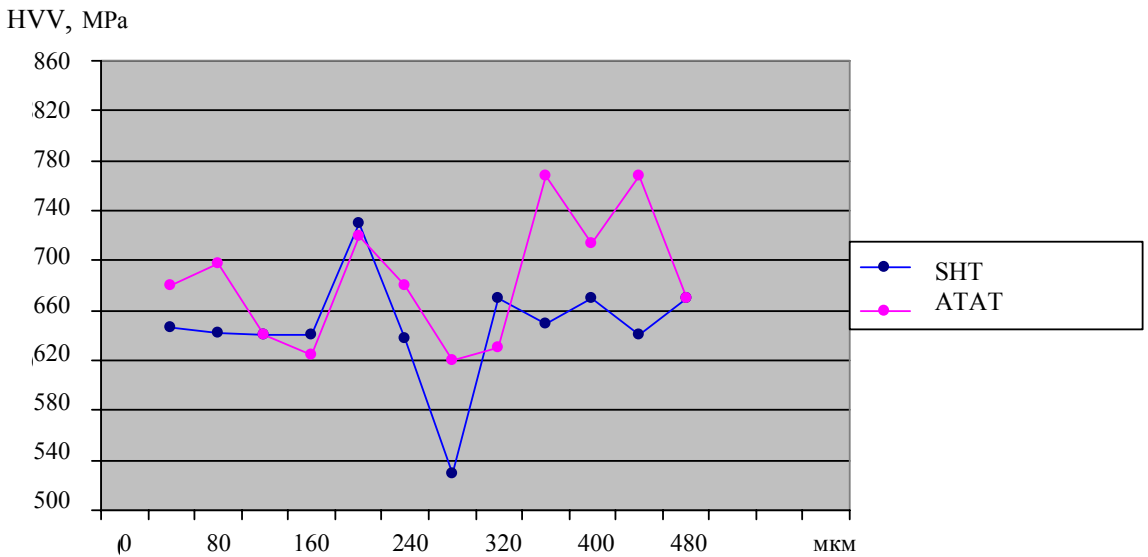

Fig. 2. Graph of the change in microhardness from the surface to the center of the section after SHT and ATAT

It can be seen that the microhardness in the surface layer of 100-150 $\mu \mathrm{m}$ from the edge of the drill in the material after the ATAT is lower than after the SHT. With further distance from the surface, the character of the change in microhardness in the initial and processed drills is the same. Closer to the middle - the microhardness of the drill after ATAT is higher than after the SHT.

Table 4

Comparison of the microhardness of rapid steel grades $\mathrm{HCV}$ and $\mathrm{HS}$

\begin{tabular}{|c|c|c|c|}
\hline Material & $\begin{array}{c}\mathrm{HV}_{\text {average}}, \\
\mathrm{MPa}\end{array}$ & $\begin{array}{c}\mathrm{HV}_{\text {min }}, \\
\mathrm{MPa}\end{array}$ & $\begin{array}{c}\mathrm{HV}_{\text {max }}, \\
\mathrm{MPa}\end{array}$ \\
\hline Steel HCV & 1019 & 824 & 1238 \\
\hline Steel HS & 580 & 420 & 824 \\
\hline
\end{tabular}

The initial drill (after SHT) was drilled 28 holes, and after aerothermoacoustic processing - 192 holes. Thus, the drills made of rapid steel after aerothermoacoustic processing are approximately 6.8 times stronger and more productive than similar drills after standard processing.

From the obtained data it can be concluded that the technology of aerothermoacoustic processing of tool steels shows a significant improvement in the strength properties of the drills being studied, and has undeniable advantages over standard processing methods.

Thus, the effect of processing on tool steel is manifested in a change in the quantitative characteristics of the structure - a more uniform distribution of carbides, grinding them and grain, i.e. in the homogenization of the structure. Practically in all cas- 
es in tool steels after ATAT, an increase in microhardness from 10 to 33 percent is observed, with respect to SHT. Also, a homogenization of the structure is observed - grinding of carbides and austenite grain after this type of processing.

\section{Qualimetric estimation of rapid steels processed by aerothermoacoustic method}

\section{Desirability function}

The evaluation of the quality characteristics of billets treated with the aerothermoacoustic method, in comparison with the quality characteristics of billets obtained by standard methods of processing, is possible by means of the desirability function [4].

Desirability indicators are dimensionless nondiscrete quality characteristics that vary from zero to one in any range of dimensional quality indicators $x_{i}$.

The basis for constructing a generalized function is the idea of transformation the natural values of particular parameters into a dimensionless desirability scale. The desirability parameters $q$ are calculated using the auxiliary parameters y (particular optimization parameters) according to the following formula:

$$
q=\exp [-1 / y]=\frac{1}{e^{1 / y}}-\text { для } 0<\mathrm{y}<\infty
$$

Dimension values $x_{i}$ of natural quality indicators are recalculated into dimensionless auxiliary parameters $y$ by the formula:

$$
y=a_{0}+a_{1} x_{i}
$$

As indicators of the quality of the blanks, the microhardness and the size of the carbides were selected. The initial information for constructing the nomogram of desirability is given in Table 5.

Data for determining the dimensional desirability

Table 5

\begin{tabular}{|c|c|c|c|c|}
\hline \multirow[b]{2}{*}{ № } & \multirow{2}{*}{\multicolumn{2}{|c|}{$\begin{array}{l}\text { Type of treat- } \\
\text { ment }\end{array}$}} & \multicolumn{2}{|c|}{ Quality characteristics } \\
\hline & & & $\begin{array}{c}\text { microhardness } \\
\text { HV }\end{array}$ & $\begin{array}{l}\text { size of car- } \\
\text { bides, } \mu \mathrm{m}\end{array}$ \\
\hline 1 & \multicolumn{2}{|c|}{ SHT } & 739 & 7,67 \\
\hline 2 & \multicolumn{2}{|c|}{ ATAT } & 860 & 7,47 \\
\hline \multirow{2}{*}{3} & \multirow{2}{*}{ GOST } & the best & 836 (63 HRC) & 15,00 \\
\hline & & minimal & 777 (62 HRC) & 100,00 \\
\hline
\end{tabular}

parameters, $x_{i}$

To transfer the values of microhardness to a dimensionless scale, the following system of equations was solved:

$$
\left\{\begin{array} { l } 
{ 4 , 5 = a _ { 0 } + 8 3 6 a _ { 1 } } \\
{ 1 , 0 = a _ { 0 } + 7 7 7 a _ { 1 } }
\end{array} \quad \left\{\begin{array}{l}
a_{0}=-44,824 \\
a_{1}=0,059
\end{array}\right.\right.
$$

Thus, substituting the actual data (microhardness according to Vickers $762 \mathrm{HV}$ and $860 \mathrm{HV}$ in equations (1) and (2), it turns out:

$$
\begin{aligned}
& \mathrm{y}=\mathrm{a}_{0}+\mathrm{a}_{1} \mathrm{x}_{\mathrm{i}}=-44,824+0,059 \cdot 739=0,134 ; \\
& q=\exp [-1 / y]=\exp [-1 / 0,134]=0,0006 . \\
& \mathrm{y}=\mathrm{a}_{0}+\mathrm{a}_{1} \mathrm{x}_{\mathrm{i}}=-44,824+0,059 \cdot 860=5,916 ; \\
& q=\exp [-1 / y]=\exp [-1 / 5,916]=0,844 .
\end{aligned}
$$

Similarly, the values of the desirability indices and the corresponding dimensionless auxiliary parameters for the size of the carbides are found.

The quality grades are selected in accordance with the data in Table 6.

Table 6

The values of the desirability indicators $\mathrm{q}$ and the corresponding dimensionless auxiliary indicators $y$

\begin{tabular}{|c|c|c|}
\hline $\begin{array}{c}\text { Gradation } \\
\text { of quality }\end{array}$ & $\begin{array}{c}\text { Index } \\
\text { desirability } q\end{array}$ & $\begin{array}{c}\text { Auxiliary } \\
\text { index } y\end{array}$ \\
\hline «Excellent» & $>0,9$ & $>10$ \\
\hline «Splendid» & $\geq 0,80$ & $\geq 4,50$ \\
\hline «Good» & $\geq 0,63$ & $\geq 2,18$ \\
\hline «Satisfactorily» & $\geq 0,37$ & $\geq 1,00$ \\
\hline «Bad» & $<0,37$ & $<1,00$ \\
\hline
\end{tabular}

The calculated data for the construction of nomograms of desirability are given in Table 7.

Table 7

Values of desirability indicators and corresponding dimensionless auxiliary indicators

\begin{tabular}{|c|c|c|c|c|}
\hline \multirow{2}{*}{$№$} & \multicolumn{4}{|c|}{ Evaluation of changes in quality indicators } \\
\cline { 2 - 5 } & \multicolumn{2}{|c|}{ Microhardness HV } & \multicolumn{2}{c|}{ The size of carbides } \\
\hline & $y$ & $q$ & $y$ & $q$ \\
\hline 1 & 0,134 & 0,0006 & 39,23 & 0,97 \\
\hline 2 & 5,916 & 0,844 & 38,168 & 0,97 \\
\hline
\end{tabular}

The nomogram of desirability for the considered quality indicators is shown in Fig. 3.

When analyzing the nomogram of desirability, the following conclusions can be drawn: - microhardness of a drill made of rapid steel R6M5 after aerothermoacoustic treatment corresponds to the level of desirability «excellent», and the size of carbides of this sample is «excellent»; - while the microhardness of drills obtained after standard processing corresponds to the level of desirability «bad», but the size of carbides corresponds to the level of «excellent» 


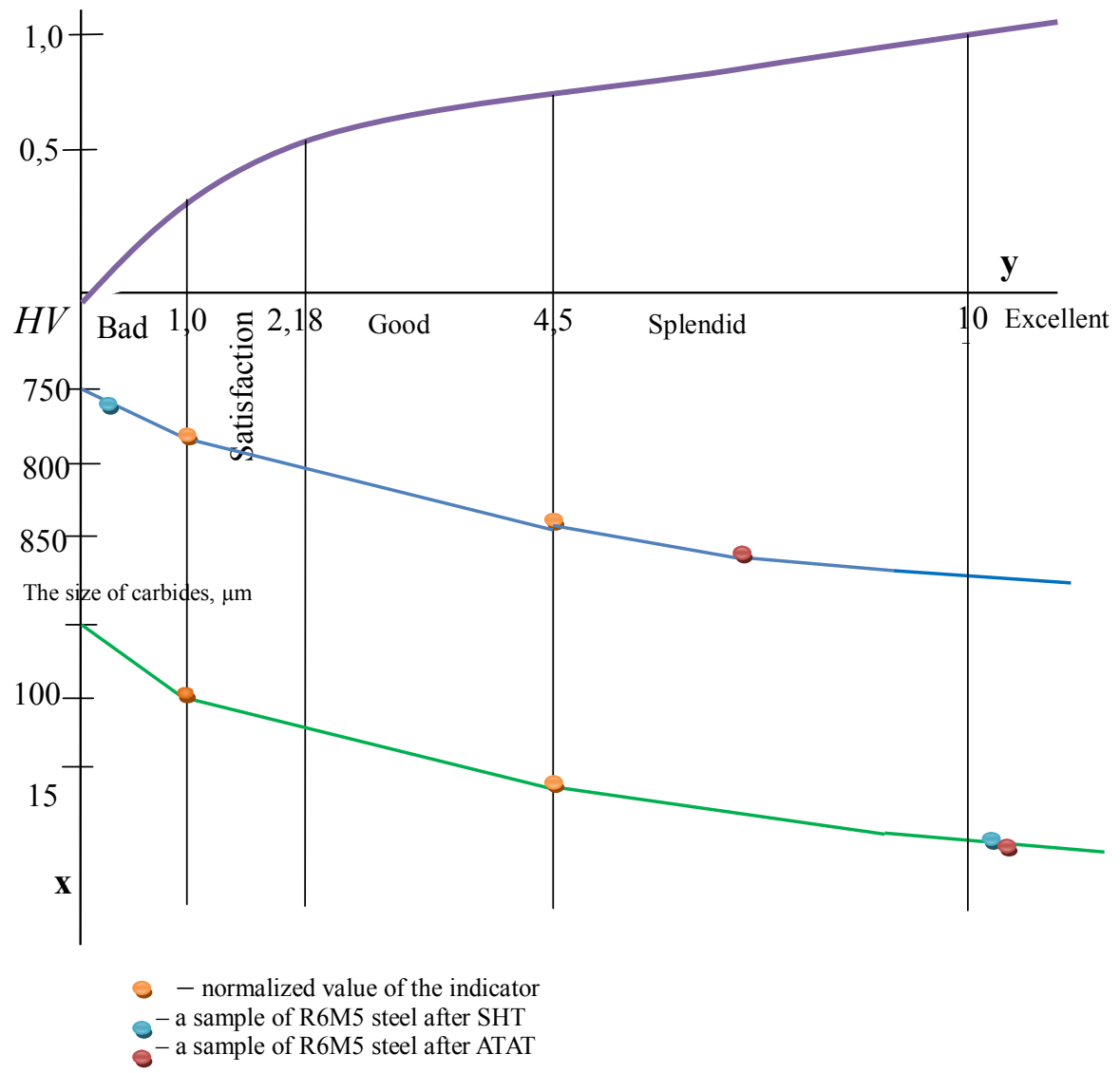

Fig. 3. Nomogram of the desirability index

Table 8

\section{Cobweb of quality}

Of the characteristics revealed in the metallographic study and the study of strength properties, it is possible to form a comparison table for these values. A comparison of the microhardness of 8 samples after SHT and ATAT is given in Table 2. A comparison of the structure characteristics in the surface layer and the center of the drill made of steel R6M5 is given in Table 3. Based on them, it is possible to build a cobweb of quality and compare the obtained characteristics using the differential method.
Relative parameters of microhardness

\begin{tabular}{|c|c|c|c|}
\hline № & Drill size & Treatment & $\begin{array}{c}\text { Relative parameters } \\
\text { of microhardness }\end{array}$ \\
\hline 1 & \multirow{2}{*}{$\begin{array}{c}\varnothing 3 \mathrm{~mm} l=135 \\
\mathrm{~mm}\end{array}$} & SHT & 1 \\
\hline 2 & & ATAT & 1,33 \\
\hline 3 & \multirow{2}{*}{$\begin{array}{c}\varnothing 7 \mathrm{mм} l=135 \\
\text { мм }\end{array}$} & SHT & 1 \\
\hline 4 & & ATAT & 1,15 \\
\hline 5 & \multirow{2}{*}{$\begin{array}{c}\varnothing 3,5 \text { мм } l=70 \\
\text { мм }\end{array}$} & SHT & 1 \\
\hline 6 & & ATAT & 1,16 \\
\hline 7 & \multirow{2}{*}{$\begin{array}{l}\varnothing 5 \mathrm{мм} l \\
=135 \mathrm{~mm}\end{array}$} & SHT & 1 \\
\hline 8 & & ATAT & 1,31 \\
\hline
\end{tabular}


Table 9

Relative indicators of the quality of R6M5 steel in the surface layer

\begin{tabular}{|c|c|c|c|c|}
\hline Material & $\begin{array}{c}\text { Grinding } \\
\text { of grain }\end{array}$ & $\begin{array}{c}\text { Crushing of } \\
\text { carbides }\end{array}$ & $\begin{array}{c}\text { Micro- } \\
\text { hardness }\end{array}$ & $\begin{array}{c}\text { Carbide het- } \\
\text { erogeneity }\end{array}$ \\
\hline $\begin{array}{c}\text { SHT } \\
\text { surface }\end{array}$ & 1 & 1 & 1 & 1 (no) \\
\hline $\begin{array}{c}\text { ATAO } \\
\text { Surface }\end{array}$ & 1,1 & 1,1 & 0,94 & 1 (no) \\
\hline
\end{tabular}

Table 10

Relative indicators of the quality of R6M5 steel in the center of the drill

\begin{tabular}{|c|c|c|c|c|}
\hline Material & $\begin{array}{c}\text { Grinding } \\
\text { of grain }\end{array}$ & $\begin{array}{c}\text { Crushing } \\
\text { of carbides }\end{array}$ & $\begin{array}{c}\text { Micro- } \\
\text { hardness }\end{array}$ & $\begin{array}{c}\text { Carbide het- } \\
\text { erogeneity }\end{array}$ \\
\hline $\begin{array}{c}\text { SHT } \\
\text { center }\end{array}$ & 1 & 1 & 1 & 1 (no) \\
\hline $\begin{array}{c}\text { ATAT } \\
\text { center }\end{array}$ & 1,17 & 1,05 & 1,1 & 1 (no) \\
\hline
\end{tabular}

From the cobweb (Figure 4) it is clear that the area of the polygon occupied by the standard type of processing is much smaller than the area of the polygon occupied by the aerothermoacoustic type of processing, which indicates an improvement in the quality of drills of different diameters and lengths in the transition to ATAT. Similarly, it is possible to build quality cobwebs for microstructural characteristics in the surface and center of the drill. The obtained data showed that both in the surface layer and in the center of the drill, grinding of large and small carbides and austenite grains occurs in steels after ATAT.

From the constructed quality cobweb it is seen that the ATAT occupies a stronger position than the SHT in the center of the drill for such parameters of quality as grinding of carbides, grain refinement, increase in microhardness, which confirms the expediency of this treatment for hardening of tool steels.

From the constructed quality cobweb, one can conclude that the aerothermoacoustic treatment has a positive effect on the increase in the quality characteristics of tool steels. In almost all cases, in these steels after ATAT, an increase in the microhardness from 10 to 33 percent is observed, with respect to SHT. Also, a homogenization of the structure is observed - grinding of carbides and austenite grain after ATAT processing.

\section{Conclusion}

During this investigation peculiarity of tool steels microstructure formation during the realiza- tion of different regimes of aerothermoacoustic treatment combined with conventional heat treatment regimes in different combinations and variations of mechanical properties and performance characteristics determining indicators durability and strength were studied.

1. The effect of aerothermoacoustic treatment on the structure of the materials under study was revealed. It was found that homogenization of the structure is observed during the processing. In a number of cases (tool steel R6M5), grinding of grain and reduction in the size of carbides are observed.

2. Rapid steel drill after aerothermoacoustic treatment is approximately 6.8 times stronger and more productive than similar drills after standard processing.

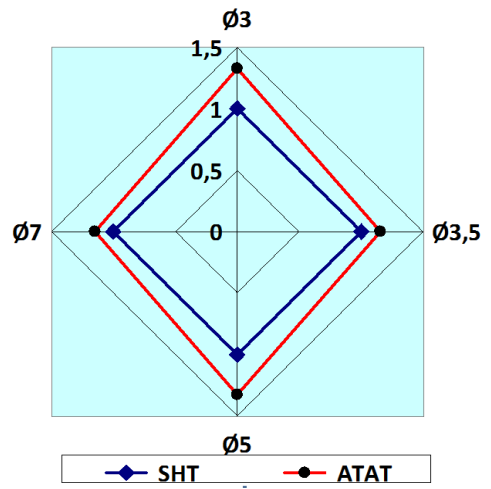

Fig. 4. Cobweb of comparison of microhardness of 8 drills after SRT and ATAO

3. In almost all cases, in these steels after ATAT, an increase in the microhardness from 10 to 33 percent is observed, with respect to SHT. Also, a homogenization of the structure is observed grinding of carbides and austenite grain after this type of processing.

Thus, ATAT technologies provide a significant increase in the strength characteristics of tool steels in comparison with traditional methods of heat treatment. Application of aerothermoacoustic processing technology makes it possible to effectively realize the reserves of durability of the cutting tool. Consequently, it can be used in tool production to increase the strength characteristics of high-speed steels.

This study was carried out with the financial support of the Russian Foundation for Basic Research (project no. 16-01-00638a). 


\section{References}

1. Atroshenko S.A., Lamonova O.A. Study on the influence of aerothermoacoustic treatment on the quality of high-speed steels. Vestnik INZhEKONa [Vestnik of Saint-Petersburg State University of Engineering and Economics. Series: Technical Sciences], 2009, no. 8 (35), pp. 95-107. (In Russ.)

2. Vorobyeva G.A., Skladnova E.E., Leonov A.F., Erofeev V.K.
Instrumentalnye materialy: uchebnoe posobie dlya studentov vuzov [Tool materials: Training manual for university students]. S. Petersburg: Polytechnic, 2005, 267 p. (In Russ.)

3. Erofeev V.K., Vorobyova G.A., Genkin P.G. Aerothermoacoustic treatment of metals and alloys. Metalloobrabotka [Metal working], 2001, no. 6, pp. 18-22. (In Russ.)

4. E.C. Harrington. Industrial Quality Control, 21 (1965), 494 p.

Received 14/03/18

Accepted 10/09/18

ИНФОРМАЦИЯ О СТАТЬЕ НА РУССКОМ ЯЗЫКЕ

УДК 621.78

https://doi.org/10.18503/1995-2732-2018-16-4-50-56

\section{ВЛИЯНИЕ АЭРОТЕРМОАКУСТИЧЕСКОЙ ОБРАБОТКИ НА ХАРАКТЕРИСТИКИ БЫСТРОРЕЖУЩИХ СТАЛЕЙ}

Атрошенко С.А.

Институт проблем машиноведения РАН, г. Санкт-Петербург, Россия

Аннотация. Работа посвящена повышению эксплуатационных характеристик быстрорежущих сталей. Объектом исследования является изменение микроструктуры в процессе аэротермоакустической обработки при сравнении со стандартными видами термической обработки и изменение при этом характеристик быстрорежущих сталей. Основной достигнутый результат работы - выявление зависимости влияния режимов аэротермоакустической обработки на поведение быстрорежущих сталей. Выяснено, что применение аэротермоакустической обработки может ис- пользоваться для увеличения прочностных характеристик быстрорежущих сталей. Оценка влияния аэротермоакустической обработки на характеристики быстрорежущих сталей проведена квалиметрическим методом

Ключевые слова: аэротермоакустическая обработка, быстрорежущая сталь; прочностные характеристики.

Исследование проведено при поддержке Российского фонда фундаментальных исследований (проект № 16-01-00638а).

Поступила 14.03.18

Принята в печать 10.09 .18

\section{Образец для цитирования}

Атрошенко С.А. Влияние аэротермоакустической обработки на характеристики быстрорежущих сталей // Вестник Магнитогорского государственного технического университета им. Г.И. Носова. 2018. Т.16. №4. С. 50-56. https://doi.org/10.18503/1995-2732-2018-16-3-50-56

For citation

Atroshenko S.A. Changes in the characteristics of tool steel after aerothermoacoustic treatment. Vestnik Magnitogorskogo Gosudarstvennogo Tekhnicheskogo Universiteta im. G.I. Nosova [Vestnik of Nosov Magnitogorsk State Technical University]. 2018, vol. 16, no. 4, pp. 50-56. https://doi.org/10.18503/1995-2732-2018-16-3-50-56 